\title{
Correction to: Bernard, Sylvain, Michel Farge (edd.): Les mutations contemporaines du droit de la famille
}

\section{Grenoble, Presses Universitaires de Grenoble, coll. « Droit et action publique», 2019, 212 p, € 27 (Paperback), ISBN 978-2-7061-4410-3}

\section{Paulina Mazurkiewicz ${ }^{1}$ []}

Published online: 20 November 2021

(c) The Author(s) 2021

\section{Correction to: Int J Semiot Law https://doi.org/10.1007/s11196-021-09826-w}

In the original publication of the article, the affiliation details for the author (Paulina Mazurkiewicz) were incorrectly given as 'Lublin, Poland' but should have been 'Université Catholique de Lublin Jean-Paul II, Lublin, Poland'. This has been corrected with this Correction.

The original article has been corrected.

Open Access This article is licensed under a Creative Commons Attribution 4.0 International License, which permits use, sharing, adaptation, distribution and reproduction in any medium or format, as long as you give appropriate credit to the original author(s) and the source, provide a link to the Creative Commons licence, and indicate if changes were made. The images or other third party material in this article are included in the article's Creative Commons licence, unless indicated otherwise in a credit line to the material. If material is not included in the article's Creative Commons licence and your intended use is not permitted by statutory regulation or exceeds the permitted use, you will need to obtain permission directly from the copyright holder. To view a copy of this licence, visit http://creativecommons.org/licen ses/by/4.0/.

Publisher's Note Springer Nature remains neutral with regard to jurisdictional claims in published maps and institutional affiliations.

The original article can be found online at https://doi.org/10.1007/s11196-021-09826-w.

Paulina Mazurkiewicz

paulina.mazurkiewicz@kul.pl

1 Université Catholique de Lublin Jean-Paul II, Lublin, Poland 